\title{
Stature Estimation Using Per-Cutaneous Tibial Length in People of Gwalior Region
}

\author{
Dr. Akhilesh Trivedi ${ }^{1}$, Dr. Sudhir Saxena ${ }^{2}$, Dr. Rajesh Morya ${ }^{3}$, \\ Dr. Massarat Jehan ${ }^{4}$, Dr. Vipendra Bhadkaria ${ }^{1}$. \\ ${ }^{1}$ Assistant professor, Dept of Anatomy, Gajra Raja Medical College, Gwalior (MP) India. \\ ${ }^{2}$ Associate professor, Dept of Anatomy, Gajra Raja Medical College, Gwalior (MP) India.. \\ ${ }^{3}$ Post Graduate Student, Dept of Pharmacology, Gajra Raja Medical College, Gwalior (MP) India. \\ ${ }^{4}$ Post Graduate Student, Dept of Anatomy, Gajra Raja Medical College, Gwalior (MP) India
}

\begin{abstract}
:
Introduction: Stature estimation is an important part of the identification process of human skeletal remains or body parts to establish individuality of an unidentified dead, body or any mutilated part of such body by the Medico-legal expert.

Aim: The present study made an attempt to estimate the stature from per-cutaneous tibial length (PCTL) by formulating simple regression equation and multiplication factor (M.F.) for people of Gwalior region.

Method: A random sample of 270 male and 270 female students of G.R.Medical College, Gwalior between the age group of 18-21 years was chosen. PCTL of right and left side were measured with the help of spreading caliper. Stature was estimated from PCTL statistically using simple regression analysis and M.F.

Result: On computing the data, the mean PCTL for male was found to be $38.24 \pm 2.343 \mathrm{~cm}$ which was significantly $(p<0.0001)$ greater than female which was $36.064 \pm 2.464 \mathrm{~cm}$. The observed height was $164.5 \pm 8.257 \mathrm{~cm}$ and $155.3 \pm 5.854 \mathrm{~cm}$ for male and female respectively. The regression formula derived for male was $y_{0}=105.971+1.53 x(P C T L) \pm 7.452$ and for female was $y_{0}=103.76+1.43 x(P C T L) \pm 4.69$. The M.F was 4.302 for male and 4.306 for female. A significant positive correlation exists between the stature and PCTL using simple regression analysis and M.F.

Conclusion: It was concluded that the stature of a deceased person whose only body part available is a mutilated leg, can be determined by using the formula derived from the present study fairly accurately to some extent. Thus the data of this study is recommended in anthropological studies for stature estimation amongst the ethnic group under study.
\end{abstract}

Key words: Forensic Anthropology, Stature, Percutaneous Tibial Length, Height Estimation, Simple Regression Equation.

\section{Introduction}

Stature estimation is an indispensable part of the identification process of human skeletal remains or body parts[1-4]. Long bones that make up the greatest proportion of stature, that is, the femur and tibia, are more accurate than the humerus and ulna [5]. The stature of an individual can be estimated from long bones, especially the tibia and the femur as these have a direct correlation to the height of an individual [6]. Forensic anthropologists while dealing with skeletal remains have very little choice to use anatomical method for stature reconstruction due to non-availability of the complete skeleton from a scene of crime in most of the cases[7-8]. Thus, they have no choice but to use a relatively less precise method of stature reconstruction, i.e., the mathematical method, which is workable even in cases where only a part of the body [9] or part of the bone [1012] are available for analysis.

The lower limb length is the greatest contributor to the standing height, hence the most predictive equation are based on length of lower limb, the femur, Tibia and fibula[13-16]. The tibia is ideal in this application as it resists erosion and keeps its anatomical shape for long even after burial[17]. Tibia accounts for $22 \%$ of the total body length[18].

Bone and stature of an individual are influenced by numerous factors as age, gender, race, geographical climate, nutrition and genetic factors[19-23]. Hence, the correlation factors of one region will not hold good for the other, as this necessitates the researches to be done on a regional basis[16,22-24].

There are various ways to estimate stature from bones, but the most easiest and reliable method is by regression analysis[22,25-26]. Regression formulae derived from the major long bones are generally considered to be more accurate. 
However the formulae derived cannot be generalized to all population groups, hence it is necessary to derive regression equations which are region wise and population specific[23] which can be applied to estimate stature of a population from its skeletal remains.

\section{Material And Method}

Study Design: Cross Sectional study.

Selection criteria: A random sample of 540 students were taken, 270 Male and 270 female, in the age group between 18-21 years of Gajra Raja Medical College, Gwalior (Madhya Pradesh). This age group was selected because multiplication factor (M.F.) remains more or less constant in this age group[27]. The following parameters were noted- Age, Gender, Height in cms (crown heel length), Per-Cutaneous Tibial Length (PCTL) of right and left side in cms.

Exclusion criteria: Subjects who had a history of major trauma or fracture of the leg, Achondroplasia or any other congenital or hereditary bony disease was excluded from the study.

\section{Methodology}

All the measurements were taken by the same observer and with the same instrument, to avoid any technical and/or inter-observer error and to maintain reproducibility. The measurements were taken three times and their mean value was considered for estimation of height.

Standing Height (Stature) of the subject was measured in a standing position on a standard Stadiometer with both feet in close contact with each other with the trunk straight along the vertical board, and the head adjusted in Frankfurt plane. The measurement was taken in centimeters by bringing the horizontal sliding bar to the vertex.

For measuring the tibial length (PCTL) subject was asked to stand and keep his/her foot on a stool to maintain the angle between the flexor surface of leg and that of the thigh at $90^{\circ}$. Then two points were marked by skin marking pencil. Upper point $\rightarrow$ The medial most point on the upper border of medial condyle of the tibia and Lower point $\rightarrow$ Tip of medial malleolus of the tibia. Distance between two points was measured with the help of Spreading Caliper to determine tibial length.(Fig. 1)

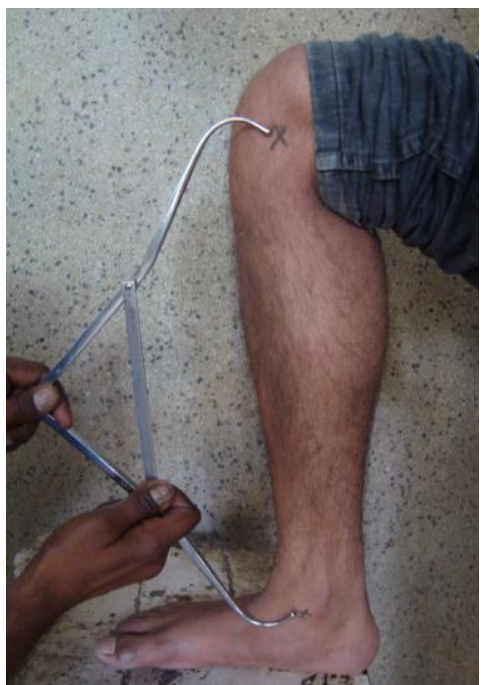

Fig.1: Method of measurement of per-cutaneous tibial length by Spreading caliper

The data was computed, tabulated and statistically analyzed using SSP 2005, Graph Pad Prism and Microsoft Excel Windows 2007 softwares. The data obtained were compared with the other similar studies.

\section{Results}

The statistical analysis of PCTL of right and left side of tibia in male and female was shown in Table 1. There was no significant difference $(p>0.05)$ in the per-cutaneous length of right and left tibia in both genders, thus showing bilateral symmetry in the length of Tibia in both gender. The mean PCTL for male was $38.24 \mathrm{~cm}$ and for female was $36.064 \mathrm{~cm}$. 
Stature Estimation Using Per-Cutaneous Tibial Length in People of Gwalior Region

Table 1: Descriptive statistics of right and left side of Tibial length

\begin{tabular}{|l|l|l|l|l|}
\hline \multirow{2}{*}{ Statistics Tibia } & \multicolumn{2}{|l|}{ Male $(\mathbf{n}=\mathbf{2 7 0})$} & Female $(\mathbf{n}=\mathbf{2 7 0})$ \\
\cline { 2 - 5 } & Rt PCTL & Lt PCTL & Rt PCTL & Lt PCTL \\
\hline Range & $34-45.8 \mathrm{~cm}$ & $34-43.7 \mathrm{~cm}$ & $32-42 \mathrm{~cm}$ & $32-48 \mathrm{~cm}$ \\
\hline Mean & $38.26 \mathrm{~cm}$ & $38.22 \mathrm{~cm}$ & $36.10 \mathrm{~cm}$ & $36.03 \mathrm{~cm}$ \\
\hline Std. Deviation & 2.451 & 2.293 & 2.429 & 0.1479 \\
\hline Std. Error & 0.1492 & 0.1396 & $6.73 \%$ & $7.26 \%$ \\
\hline Coefficient of variation $(\mathrm{CV})$ & $6.41 \%$ & $6.00 \%$ & $\mathrm{t}=0.3170 \mathrm{df}=538$ \\
\hline $\mathrm{t}-$ value & $\mathrm{t}=0.1795 \mathrm{df}=538$ & 0.7513 \\
\hline $\mathrm{p}-$ value & 0.8576 & $\mathrm{Ns}$ \\
\hline P value summary & $\mathrm{Ns}$ & $36.064 \mathrm{~cm}$ \\
\hline Average mean $(\mathrm{rt}+\mathrm{lt})$ & $38.24 \mathrm{~cm}$ &
\end{tabular}

PCTL = per-cutaneous tibial length; $\mathrm{Rt}=$ right $\mathrm{Lt}=\mathrm{left} ; \mathrm{Ns}=$ not significant $\mathrm{df}=$ degree of freedom The study revealed that standing height of many individuals were same, but their PCTL differed, i.e. the contribution of tibial length to the stature of a person varied from person to person, even for a given height[23]. Keeping this in view, Mean of stature and PCTL were taken into consideration and the data were calculated and analyzed (Table 2). The observed mean height was $164.5 \mathrm{~cm}$ and $155.3 \mathrm{~cm}$; and mean PCTL was $38.24 \mathrm{~cm}$ and $36.064 \mathrm{~cm}$ in male and female respectively which was significantly $(\mathrm{p}<0.0001)$ greater for male compared with female.

Table 2: Descriptive statistics of observed Height and Tibial length of male and female

\begin{tabular}{|c|c|c|c|c|}
\hline \multirow[t]{2}{*}{ Statistics } & \multicolumn{2}{|l|}{ Male } & \multicolumn{2}{|l|}{ Female } \\
\hline & Height & PCTL & Height & PCTL \\
\hline Range & $143-182.5 \mathrm{~cm}$ & $34-43.65 \mathrm{~cm}$ & $147-176.5 \mathrm{~cm}$ & $32-44 \mathrm{~cm}$ \\
\hline Mean & $164.5 \mathrm{~cm}$ & $38.24 \mathrm{~cm}$ & $155.3 \mathrm{~cm}$ & $36.064 \mathrm{~cm}$ \\
\hline Std. Deviation & 8.257 & 2.343 & 5.854 & 2.464 \\
\hline Std. Error & 0.5025 & 0.1426 & 0.3562 & 0.1499 \\
\hline Coefficient of variation(CV) & $5.02 \%$ & $6.13 \%$ & $3.77 \%$ & $6.83 \%$ \\
\hline \multicolumn{5}{|c|}{ Student t- test between male and female Tibial length: } \\
\hline $\mathrm{t}-$ value & $\mathrm{t}=10.50$ & & & \\
\hline $\mathrm{p}$ - value & $\mathrm{P}<0.0001$ & & & \\
\hline $\mathrm{P}$ value summary & $* * *$ Significant & & & \\
\hline Difference between means & $2.176 \pm 0.2069$ & & & \\
\hline Are means signif. different? $(\mathrm{P}<0.05)$ & Yes & & & \\
\hline $95 \%$ confidence interval & 1.767 to 2.578 & & & \\
\hline R squared & 0.1701 & & & \\
\hline Average mean PCTL(M+F) & $37.151 \mathrm{~cm}$ & & & \\
\hline
\end{tabular}

In Table 3, Correlation coefficients ( $r$ ) of height and PCTL for male and female were 0.4342 and 0.6014 respectively which were statistically significant. Since there was high correlation between the height and PCTL, a simple regression analysis was done between them for males and females and a simple regression formula was derived to predict height from PCTL. The regression formula derived for male was $\mathrm{y}_{0}=105.971+1.53 \times($ PCTL $) \pm 7.452$ and for female was $\mathrm{y}_{0}=103.76+1.43 \times($ PCTL $) \pm 4.69$. The predicted height (y) so derived was acceptable within a range of error and was in close approximation with that of the observed height.

Table 3: Formulation of Regression equation for calculating the stature from PCTL in male and female

\begin{tabular}{|c|c|c|c|c|c|c|}
\hline \multirow{2}{*}{$\begin{array}{l}\text { Regression Statistics } \\
\text { of Tibia }\end{array}$} & \multicolumn{3}{|c|}{ Male (observed ht=164.5cm) } & \multicolumn{3}{|c|}{ Female $($ observed $\mathrm{ht}=155.3 \mathrm{~cm}$ ) } \\
\hline & $\mathbf{R t}$ & Lt & $\begin{array}{l}\text { Average } \\
\text { PCTL(rt+lt) }\end{array}$ & $\mathbf{R t}$ & Lt & $\begin{array}{l}\text { Average } \\
\text { PCTL(rt+lt) }\end{array}$ \\
\hline $\begin{array}{l}\text { Independent } \\
\operatorname{variable}(\mathrm{x})=\text { PCTL }\end{array}$ & $\mathrm{x}_{1}=38.26$ & $\mathrm{x}_{2}=38.22$ & $\mathrm{x}_{0}=38.24$ & $\mathrm{x}_{1}=36.10$ & $\mathrm{x}_{2}=36.03$ & $\mathrm{x}_{0}=36.064$ \\
\hline Intercept (a) & 110.76 & 103.712 & 105.971 & 105.724 & 106.64 & 103.76 \\
\hline $\begin{array}{l}\text { Regression coefficient } \\
\text { (b) }\end{array}$ & 1.404 & 1.59 & 1.53 & 1.373 & 1.35 & 1.43 \\
\hline $\begin{array}{l}\text { Correlation } \\
\text { coefficient(r) }\end{array}$ & 0.4168 & 0.4416 & 0.4342 & 0.5699 & 0.6036 & 0.6014 \\
\hline $\begin{array}{l}\text { Coefficient } \\
\text { determination }\left(\mathrm{R}^{2}\right)\end{array}$ & 0.174 & 0.195 & 0.189 & 0.325 & 0.364 & 0.362 \\
\hline $\begin{array}{l}\text { Std. error of estimate } \\
\text { (SEE) }\end{array}$ & 7.52 & 7.422 & 7.452 & 4.82 & 4.68 & 4.69 \\
\hline Significance (p) & $* * *$ & $* * *$ & $* * *$ & **** & **** & $* * *$ \\
\hline $\begin{array}{l}\text { Regression formula } \\
(y=a+b x)\end{array}$ & $\begin{array}{l}\mathrm{y}_{1}=110.76+ \\
1.404(\mathrm{x}) \mathrm{x}_{1}\end{array}$ & $\begin{array}{l}\mathrm{y}_{2}=103.712+ \\
1.59(\mathrm{x}) \mathrm{x}_{2}\end{array}$ & $\begin{array}{l}y_{0}=105.971+ \\
1.53(x) x_{0}\end{array}$ & $\begin{array}{l}\mathrm{y}_{1}=105.724+ \\
1.373(\mathrm{x}) \mathrm{x}_{1}\end{array}$ & $\begin{array}{l}\mathrm{y}_{2}=106.64+ \\
1.35(\mathrm{x}) \mathrm{x}_{2}\end{array}$ & $\begin{array}{l}y_{0}=103.76+ \\
1.43(x) x_{0}\end{array}$ \\
\hline Predicted ht $(\mathrm{y})$ & $164.484 \mathrm{~cm}$ & $164.478 \mathrm{~cm}$ & $164.478 \mathrm{~cm}$ & $155.289 \mathrm{~cm}$ & $155.289 \mathrm{~cm}$ & $155.289 \mathrm{~cm}$ \\
\hline
\end{tabular}

$* * *$ Significant at $\mathrm{p}<0.0001 ; \mathrm{rt}=$ right; $\mathrm{lt}=$ left. 
The positive correlation of Length of Tibia (mean= $38.24 \mathrm{~cm}$ ) on $\mathrm{X}$-axis and Height of male subjects $($ mean $=164.5 \mathrm{~cm})$ on $\mathrm{y}$-axis (Graph 1), indicating that increase in length of tibia leads to increase in total height of male subject $(r=0.4342, \mathrm{P}<0.0001)$. The significant correlation was further interpreted by linear regression.

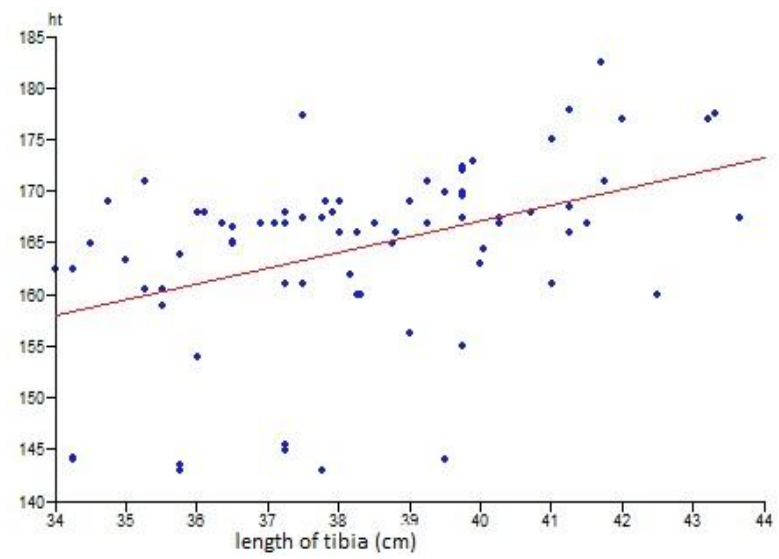

Graph 1: Showing relation between length of tibia(PCTL) and height in male

The positive correlation of Length of Tibia (mean= $36.064 \mathrm{~cm}$ ) on $\mathrm{X}$-axis and Height of female subjects $($ mean $=155.3 \mathrm{~cm})$ on $y$-axis (Graph 2), indicating that increase in length of tibia leads to increase in total height of female subject $(r=0.6014, \mathrm{P}<0.0001)$. The significant correlation was further interpreted by linear regression.

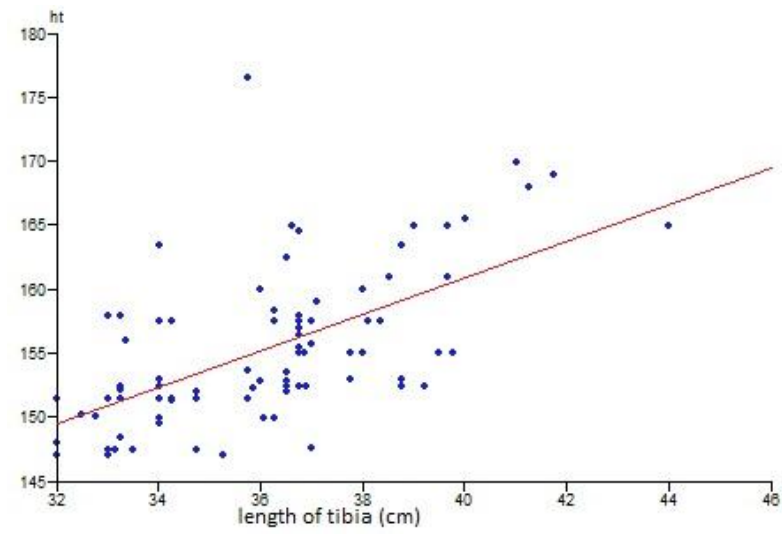

Graph 2: Showing relation between length of tibia (PCTL) and height in female

We have also estimated the multiplication factor (M.F.) for PCTL (Table 4 ). The average M.F. was found to be 4.302 in male and 4.306 in female. With the help of this multiplication factor the average stature was calculated as $164.5 \mathrm{~cm}$ for male and $155.292 \mathrm{~cm}$ for female which showed the average error of $0.00 \mathrm{~cm}$ in male and $0.008 \mathrm{~cm}$ in female.

Table 4: Multiplication factor (M.F.) in both gender for tibial length

\begin{tabular}{|l|l|l|l|l|}
\hline \multirow{2}{*}{ Tibia } & Male & Female \\
\cline { 2 - 5 } & Rt & Lt & Rt & $36.099 \mathrm{~cm}$ \\
\hline PCTL & $38.26 \mathrm{~cm}$ & $38.22 \mathrm{~cm}$ & 3.302 & \\
\hline M.F. & 4.299 & 4.304 & $4.03 \mathrm{~cm}$ \\
\hline Average M.F. & 4.302 & & 4.3099 \\
\hline Calculated average Stature & $164.5 \mathrm{~cm}$ & $155.292 \mathrm{~cm}$ \\
\hline
\end{tabular}

The stature estimated from PCTL with the help of formulated M.F. was compared with stature estimated by regression formula, the average error was found to be $0.022 \mathrm{~cm}$ in male and $0.003 \mathrm{~cm}$ in female. The average error was nearly insignificant and less than $1 \mathrm{~cm}$; hence multiplication factor can also be used as a formula for estimation of stature. 


\section{Discussion}

The earlier studies established that the means of stature reconstruction, i.e. M.F or regression formulae are both population and gender specific and thus it is important to first identify the recovered remains and then relevant measurements should be taken to reconstruct the stature. Though both the methods may be used, but regression equations provide greater reliability in estimated stature $[8,19]$. We have also derived regression formula and M.F. both.

Kaore et al [16] reported that the Regression formulae are more dependable than multiplication factor for estimation of stature. Kate and Muzumdar[28] after comparing the derived regression equation for Maharashtrian and Punjabis with that of Pearson's regression formula derived from English bone stated that Pearson's regression equation does not give exact results in Indian population. Similar view by Kaore et al[16]. They suggested that the regression formula derived by Allbrook [7] for estimating the stature in the British population is not suitable to estimate the stature in Indian population.[16,28]

As individuals stop growing in height on completion of the union of the epiphysis and the diaphysis, which is usually by the age of 18 to 20 years, therefore all the individuals considered for the purpose of the study were either at or above the age of 20years. In this study, the mean height for male was $164.5 \pm 8.257 \mathrm{~cm}$ and for female was $155.3 \pm 5.854 \mathrm{~cm}$; and the mean PCTL for male was $38.24 \pm 2.343 \mathrm{~cm}$ which was significantly $(\mathrm{p}<0.0001)$ greater than the female which was $36.064 \pm 2.464 \mathrm{~cm}$.

Our findings are similar to that of Yayim Yili[29], Agnihotri et al[30], Chavan et al[23], Bhavna and Surinder Nath $[8,19]$ and many others, who observed that there was no statistically significant difference in the length of right and left tibia in both males and females.

Mukta Rani [31] compared the bilateral percutaneous measurement of tibia and expressed that left tibia is longer than the right tibia in both sexes.

Allbrook [7] in 1961, compared both estimated stature derived from length of dried tibia and from the average percutaneous tibial length. There was no difference in stature estimated from two different sets of tibia. The average stature was $170.06 \mathrm{~cm}$ for British male population.

Chavan et al [23] estimated the mean height of male and female to be $167.89 \mathrm{~cm} \pm 6.21 \mathrm{~cm}$ and 151.41 $\mathrm{cm} \pm 5.04 \mathrm{~cm}$ respectively. Mean PCTL was $37.32 \mathrm{~cm} \pm 2.18 \mathrm{~cm}$ for male and $34.44 \mathrm{~cm} \pm 2.10 \mathrm{~cm}$ for female.

Mukta Rani et al[31] estimated the stature in students of Delhi to be $169.5 \mathrm{~cm}$ in male and $159.5 \mathrm{~cm}$ in female which were higher than our results. less than $1 \mathrm{~cm}$.

Kaore et al [16] estimated average stature $170.089 \mathrm{~cm}$ for Indian male population with an average error

Bhavna and Surender Nath[8] in their study on male Shia Muslims in Delhi derived the following linear regression equation; Height in $\mathrm{cms}=84.74+2.27 \mathrm{x}(\mathrm{PCTL}) \pm 3.67$, which is comparable to our study, but exemplifies the fact that the regression equation derived will be population group/region specific15. In our study, we assessed both males and females which has not been done in the above study.

Our estimated stature nearly correlates well with that of Bhavna and S. Nath $[8,19]$ who estimated stature to be $167.66 \mathrm{~cm}$ for males and $154.40 \mathrm{cms}$ for females.

According to Trotter and Gleser[32] world population is getting taller and therefore the relationship between height and length of long bones is changed and fresh formulae or M.F are needed for each generation, hence they attempted to find out fresh M.F for Indians.

Our values of multiplication factor are comparable with those of Bhavana and Surinder Nath[8,19] who gave the values for M.F as 4.60 in males and 4.59 in females. The M.F in our study was 4.302 for male and 4.306 for female.

Chavan et al [23] estimated the average M.F for tibia to be 4.77 in male and 4.88 in female and the average stature calculated $170.69 \mathrm{~cm}$ for male and 157.06 for female, which showed the average error of 0.61 $\mathrm{cm}$ in male and $0.86 \mathrm{~cm}$ in female.

Chavan et al [23] estimated the value of ' $r$ ' for males was 0.82 and for females 0.68 . Both these values were statistically significant. Bhavana and Surinder Nath[8] estimated $r=0.765$ for male. In our study $r=0.4342$ for male, which is smaller than other studies and $\mathrm{r}=0.6014$ for female which nearly correlates with other studies.

Petrovečki et al[4] tested a new radiographic approach to the stature prediction that could be used in the identification process of human skeletal remains of unknown identity. The stature of 19 female and 21 male adult cadavers was measured within 24 hours after death and considered equal to the living stature. The anteroposterior radiographs of all limbs were taken and the maximum length of the six long bones was measured from radiographs. There was a significant difference in the stature and maximum length of long bones between female and male cadavers ( $<0.001$ for all). The correlation between the stature and long bone length was best for the humerus in females $(\mathrm{r}=0.792)$ and the tibia in males $(\mathrm{r}=0.891)$. Regression equations specific to Croatian population were computed separately for each long bone in males and females and proven reliable in predicting the living stature of the individual. 


\section{Conclusion}

There was no significant difference in the per-cutaneous length of right and left tibia in both genders, thus showing bilateral symmetry in the length of Tibia in both genders. In both genders stature estimated by regression formulae for per-cutaneous tibial length of people of Gwalior region was similar to average measured stature with an error of less than $1 \mathrm{~cm}$ which was statistically insignificant $\mathrm{P}>0.05$. Multiplication factor for length of tibia was similar to average measured stature with an error of less than $1 \mathrm{~cm}$. This was statistically insignificant $\mathrm{P}>0.05$. It was concluded that it is possible to determine the stature of a deceased person whose only body part available is a mutilated leg, by using the data and formula derived from the present study fairly accurately to some extent. However the formulae derived cannot be generalized to all population groups, hence it is necessary to derive regression equations which are region wise and population specific. Thus the data of this study are recommended in anthropological studies for stature estimation amongst the ethnic group under study.

\section{References}

[1] Trotter M, Gleser GC. Estimation of stature from long bones of American whites and negroes. Am J Phys Anthropol 1952;10:463514.

[2] Mall G, Hubig M, Büttner A, Kuznik J, Penning R, Graw M. Gender determination and estimation of stature from the long bones of the arm. Forensic Sci Int 2001;117: 23-30.

[3] Duyar I, Pelin C. Body height estimation based on tibia length in different stature groups. Am J Phys Anthropol 2003;122:23-7.

[4] Petrovečki V, Mayer D, Šlaus M, Strinović D, Škavić J. Prediction of stature based on radiographic measurements of cadaver long bones: a study of the Croatian population. Journal of Forensic Sciences. 2007; 52 (3):547-52.

[5] Lundy JK, Feldesman MR. Revised equations for estimating living stature from long bones of the South African Negro. S Afr J Sci 1987; 83: 54-55.

[6] Brothwell D, Zakrzewski. Metric and non-metric studies of archaeological human bone. In: Brickley M, McKinley JI, editors. Stature estimation. Guidelines to the Standards for recording Human Remains. Southamp-ton/Reading: BABAO/ Institute of Field Archeologists; 2004.

[7] Allbrook D. The estimation of stature in British and East African males based on tibial and ulnar bone lengths. J. For. Med.1961; 8: 15-28.

[8] Bhavna S, Surinder Nath. Estimation of Stature on the Basis of Measurements of the Lower Limb. Anthropologist Special Volume. 2007; 3: 219-222.

[9] Ozaslan A, Iscan MY, Ozaslan I, Tugcu H, Koc S. Estimation of stature from body parts. Forensic Sci Int 2003;132:40-5.

[10] Badkur P, Nath S. Use of regression analysis in reconstruction of maximum bone length and living stature from fragmentary measures of the ulna. Forensic Sci Int 1990;45:15-25

[11] Holland TD. Estimation of adult stature from fragmentary tibias. J Forensic Sci 1992;37:1223-9.

[12] Prasad R, Vettivel S, Jeyaseelan L, Isaac B, Chandi G. Reconstruction of femur length from markers of its proximal end. Clin Anat 1996;9:28-33.

[13] Trotter M, Gleser GC. Estimation of stature from long bones of American Whites and Negroes Am. J. Phys. Anthropology. 1952; 10:463-514.

[14] Trotter M, Gleser GC. A re-evaluation of estimation of stature based on measurements of stature taken during life and of long bones after death. Am. J Phys. Anthropology.1958; 16:79-123.

[15] Lal CS, Lala JK. Estimation of height from tibial and ulnar lengths in North Bihar. Journal of Indian Medical Association .1972; 58(4):120-121.

[16] Kaore A, Kaore BP, Kamdi A, Kaore S. Stature Estimation From Tibial Length. NJIRM. 2012; 3(2):51-56.

[17] Krici Y, Ozan H. Determination of gender from the tibia of adult Turkish cadavers. Kaibogaku Zasshi. 1999; 45:537-543.

[18] Cox HWV. Medical jurisprudence and Toxicology. $6^{\text {th }}$ ed. The law book company.1990;171-174.

[19] Bhavna S, Surinder Nath. Use of Lower Limb Measurements in Reconstructing Stature among Shia Muslims. The internet Journal of Biological Anthropology. 2009; 2(2).

[20] Steele DG. Estimation of Stature from Fragments of Long limb bones, in: Stewart. T.D (ed.) Personal Identification in Mass Disasters. Smithsonian Institute: Washington D.C, $1970 ; 85-97$.

[21] Nath BS. Estimation of stature from long bones in Indians of United Provinces: A Medico-Legal enquiry in Anthropometry. Ind. J. Med Res 1931; 18: 1245-1253

[22] Kumar P, Shahnawaz K, Varma G. Study of Estimation of Stature by the Length of Femur. Journal of Evolution of Medical and Dental Sciences 2014; 3(12): 3166-72.

[23] Chavan SK, Chavan KD, Mumbre SS, Makhani CS. Stature and Percutaneus Tibial Length: A Correlational Study in Maharashtrian Population. Indian Journal of Forensic Medicine and Pathology. 2009; 2(3):109-12

[24] Siddiqui MAH, Shah MA. Estimation of Stature from long bones of Punjabis. Ind. J. Med. Res. 1944; 32: 105-108.

[25] Iscan MY. Global forensic anthropology in the 21st century (Editorial). Forensic Sci Int, 2001;117: 16.

[26] Iscan MY. Forensic anthropology of gender and body size (Editorial). Forensic Sci Int, 2005; 147: $107-112$.

[27] Lal CS, Lala JK. Estimation of height from tibial and ulnar lengths in North Bihar. Journal of Indian Medical Association.1972; 58(4):120-121.

[28] Kate BR, Majumdar RD. Stature estimation from femur and humerus by regression and autometry. Acta. Anat. 1976; 94 : $311-320$.

[29] Yayim Yili. Estimation of stature from tibial length. Journal of Forensic Medicine. 1996; 12: 87 - 93

[30] Agnihotri AK, Kachhwaha S, Jowaheer V, Singh AP. Estimating stature form percutaneous length of tibia and ulna in indoMauritian population. Forensic Science International. 2009;187 (1) : 109.el-109.e3.

[31] Rani Mukta, Tyagi AK, Verma SK, Kohli A. Estimation of stature from percutaneous measurements of legs (1999-2000). Journal of Forensic Medicine and Toxicology 2004; 21(1):12-14.

[32] Trotter M, Gleser GC. Estimation of stature from long bones of American Whites and Negroes. Am. J. Phys. Anthropology. 1952; 10:463-514. 